\title{
Mikroprocesorowe przetworniki sygnału elektrycznego na ciśnieniowy dla układów hamulcowych pojazdów trakcyjnych
}

\begin{abstract}
W artykule przedstawiono krótki przeglad stosowanych dotad w taborze kolejowym przetworników zamieniajacych sygnat elektryczny na sygnat ciśnieniowy sprężonego powietrza, które sq podstawowym elementem układów hamulca sterowanych elektrycznie. Zaproponowano nowe przetworniki, mogace znaleźć powszechne zastosowanie w układach hamulcowych pojazdów trakcyjnych sterowanych mikroprocesorowo. Omówiono prace badawczo-rozwojowe nad nowym przetwornikiem i przedstawiono wyniki prób wdrożonej do produkcji tablicy pneumatycznej hamulca dla modernizowanych lokomotyw wyposażonej w uktad nowego przetwornika.
\end{abstract}

\section{Wstęp}

Współczesne pojazdy trakcyjne posiadają wiele rozbudowanych układów hamulcowych o różnorodnej strukturze (układy pneumatyczne, elektryczne, hydrauliczne i mechaniczne hamulca). Ze względów funkcjonalnych i strukturalnych muszą one ze sobą współdziałać, oraz być zarządzane $\mathrm{w}$ prosty i bezpieczny sposób przez prowadzącego pojazd. Stosowane dotychczas $\mathrm{w}$ Polsce systemy sterowania elektropneumatycznego, a w przyszłości mikroprocesorowego, dla zapewnienia realizacji tych złożonych funkcji współczesnych układów hamulcowych, wymagają stosowania przetworników zamieniających sygnał elektryczny na odpowiednią wartość ciśnienia. Jest to jeden $\mathrm{z}$ ważniejszych podzespołów decydujący o parametrach funkcjonalnych kompletnego układu hamulcowego.

\section{Dotychczasowe rozwiązania przetworników zamieniających sygnał elektryczny na ciśnie- niowy sygnal pneumatyczny}

Przetwornik ciśnienia e/p ma za zadanie zamienić sygnały elektryczne na analogową wartość ciśnienia. Powinien również umożliwiać realizację wymaganych w układzie pneumatycznym przebiegów ciśnienia w funkcji czasu na te sygnały elektryczne.

Znane są analogowe i cyfrowe przetworniki sygnału elektrycznego na ciśnienie, bez sprzężenia i ze sprzężeniem zwrotnym. W [1] przedstawiono i omówiono budowę przetworników analogowych bez sprzężenia zwrotnego używanych w Polsce w lokomotywach EP09 (rys. 1), elektropneumatycznych przetworników

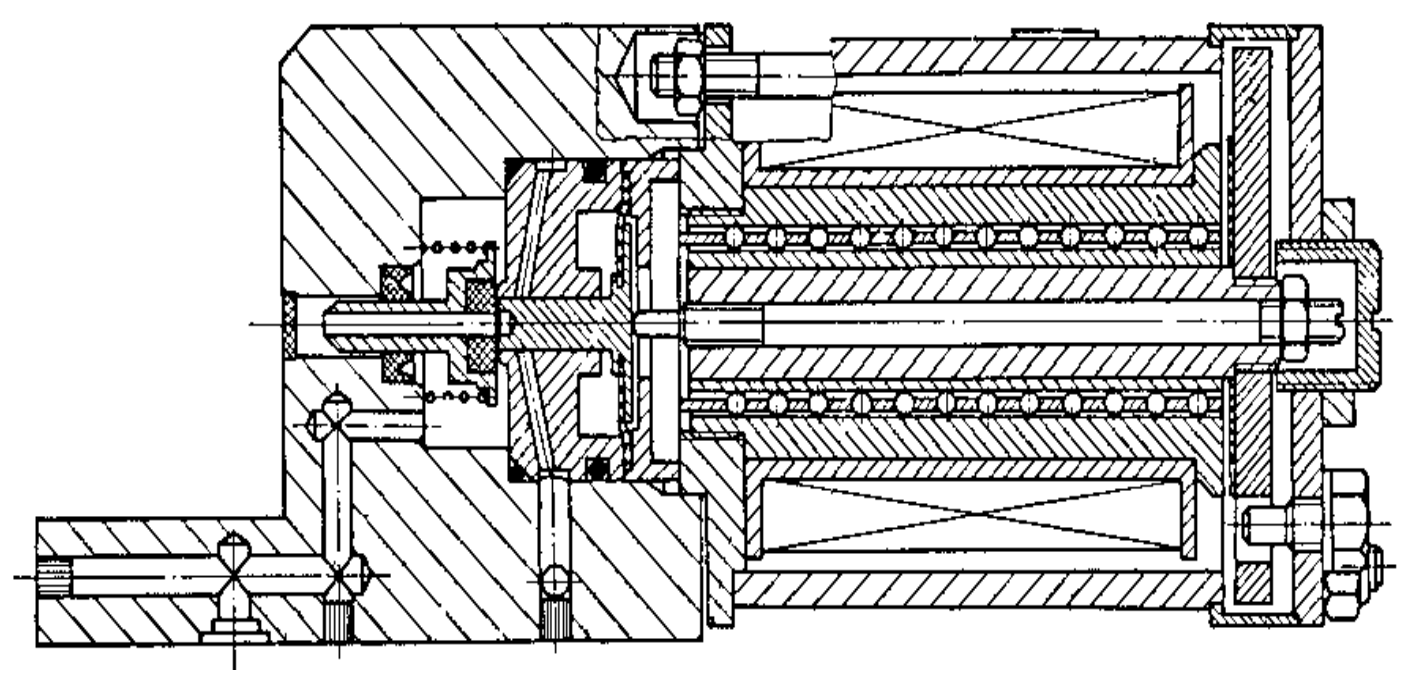

Rys.1 Przetwornik analogowy bez sprzężenia zwrotnego lokomotywy EP-09 


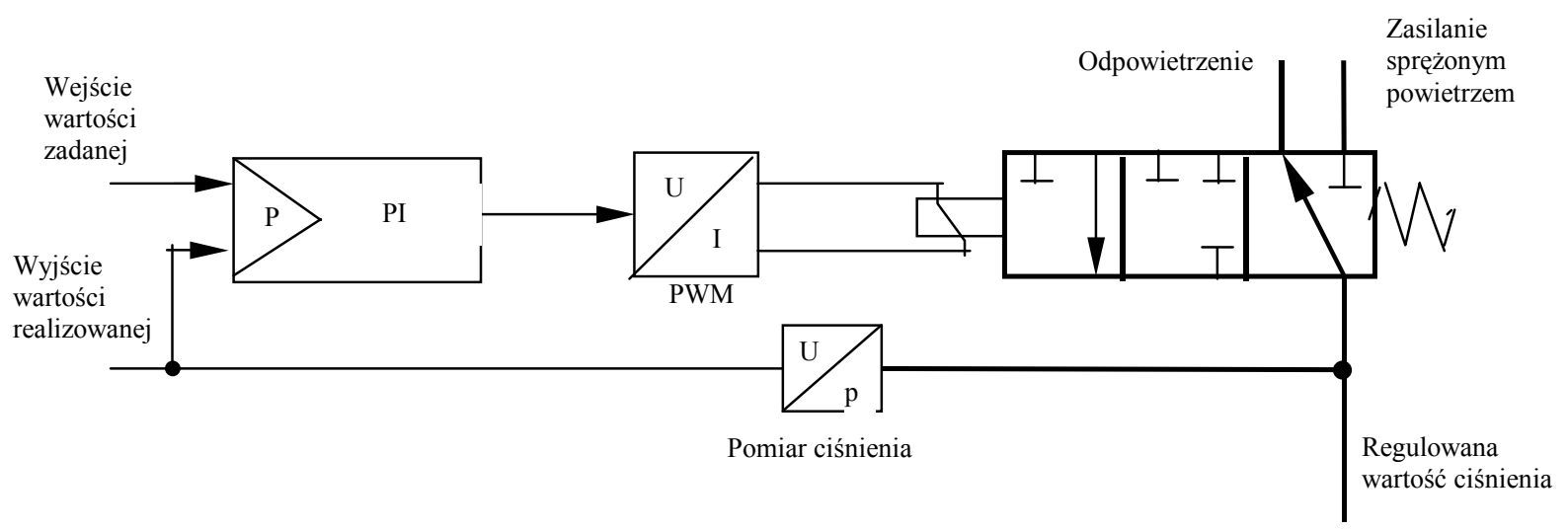

Rys. 2 Schemat przetwornika analogowego prąd-ciśnienie ze sprzężeniem zwrotnym dla modernizowanej lokomotywy EP-09

cyfrowo-analogowych stosowanych w autobusach szynowych i zespołach trakcyjnych, oraz przetwornik elektropneumatyczny analogowy sterowany binarnie lub analogowo-binarnie ze sprzężeniem zwrotnym.

Przetworniki analogowe bez sprzężenia zwrotnego charakteryzują się niezadowalającą dokładnością oraz dużą histerezą działania. Z tego powodu IPS Tabor w 2007 roku wprowadził w modernizowanych lokomotywach EP-09 w ich miejsce analogowe przetworniki ze sprzężeniem zwrotnym (z pomiarem ciśnienia regulowanego), $\mathrm{z}$ regulatorem proporcjonalno-całkującym (PI) i z układem mechaniczno-pneumatycznym napędzanym cewką zasilaną poprzez układ elektryczny z modulacją PWM (Puls with modulation - modulacja szerokością impulsu). Schemat tego przetwornika przedstawiono na rys.2. Układ ten charakteryzuje się dużą dokładnością i niewielką histerezą, ale jednocześnie wysoką cena.

Cyfrowe przetworniki bez sprzężenia zwrotnego o wymaganej dokładności działania są również kosztownymi urządzeniami zajmującymi sporo miejsca na tablicach pneumatycznych. Mimo to z dużym powodzeniem stosowane są dotychczas w układach lokomotywowych, w układach hamulcowych hamulca EP zespołów trakcyjnych i autobusach szynowych. IPS Tabor zastosował je np. w układzie hamulcowym sterowanym mikroprocesorowo dla ezt, nagrodzonym złotym medalem na Międzynarodowych Targach Poznańskich w kategorii „Transfer wyników badań naukowych do praktyki gospodarczej" w 2007 roku [2]. Na rys. 3 i 4 przedstawiono tablice hamulcowe tego układu hamulcowego, w których przetworniki te oznaczono jako „człon stopniujący hamulca PN" i „człon stopniujący hamulca EP”. Przetwarzają one binarne sygnały elektryczne na ściśle określone w konstrukcji przetwornika poziomy ciśnienia, realizowane określonymi gradientami ciśnienia. Ze względu na wysoką cenę wyżej omówionych przetworników i brakiem możliwości generowania dowolnych wartości ciśnień i realizowanych gradientów, IPS poszukuje innych tańszych rozwiązań przetworników zapewniających dużą dokładność, małą histerezę i dużą niezawodność działania.

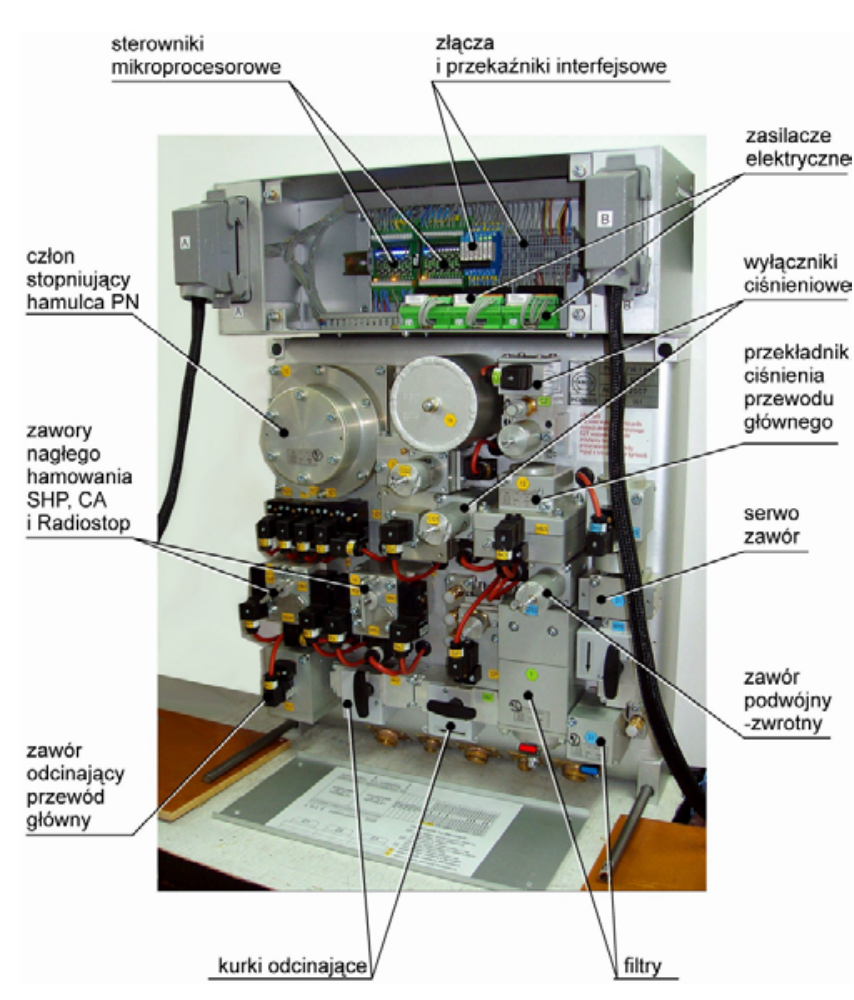

Rys.3 Sterująca tablica hamulcowa ezt

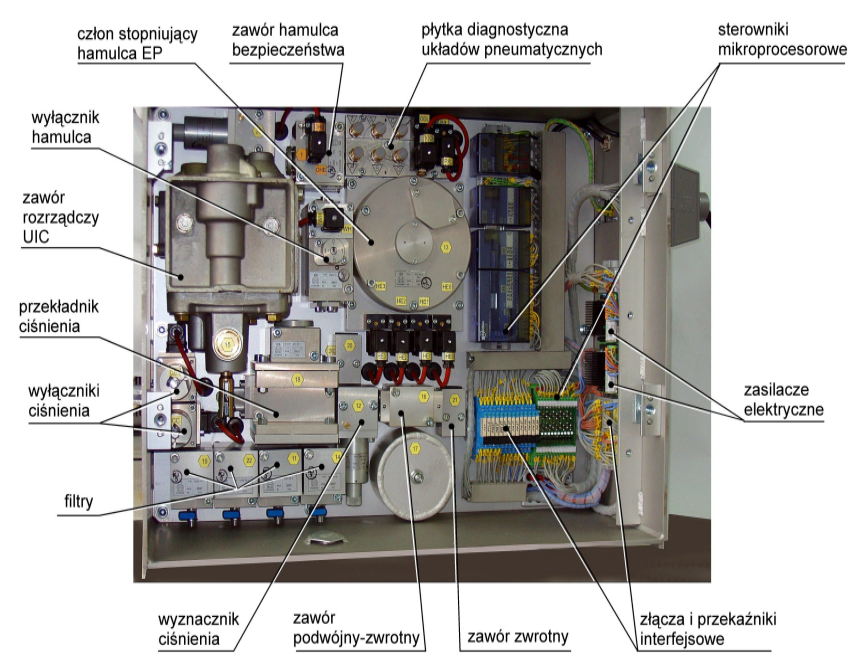

Rys.4 Wagonowa tablica hamulcowa 


\section{Przetwornik cyfrowo-analogowy ze sprzężeniem zwrotnym}

We współczesnych układach hamulcowych zintegrowanych na tablicach pneumatycznych, coraz częściej stosowane są do celów sterowania i diagnostyki mikroprocesorowe układy sterujące $\mathrm{z}$ analogowymi lub cyfrowymi pomiarami ciśnień. Wobec istnienia na tablicach pneumatycznych tych elementów celowe wydaje się wykorzystanie ich w układach przetwornika ciśnienia $e / p \quad \mathrm{z}$ pomiarowym sprzężeniem zwrotnym. Koszt takiego przetwornika cyfrowego z pomiarem ciśnienia regulowanego mógłby być wówczas niewielki.

Cyfrowy przetwornik ciśnienia $e / p$ zamieniający elektryczne sygnały, pochodzace ze sterownika mikroprocesorowego na wymagane wartości ciśnienia zbudowany byłby $\mathrm{z}$ następujących elementów:

- istniejącego sterownika mikroprocesorowego pneumatyki pracującego $\mathrm{W}$ układzie rozproszonym na pojeździe,

- istniejącego czujnika pomiarowego ciśnienia $p / i$,

- istniejącej komory sterującej,

- zespołu zaworów elektropneumatycznych napełniających i opróżniających do dowolnego wymaganego poziomu i w wymaganym tempie komorę sterująca przekładnika. Zespół zaworów składać się będzie z zaworów napełniających i opróżniających. Najlepszym rozwiązaniem byłoby zastosowanie zaworów elektropneumatycznych proporcjonalnych (realizujących zmienne natężenie przepływu w funkcji napięcia lub prądu zasilającego zawór). Wówczas w układzie byłby zastosowany tylko jeden zawór napełniający i jeden zawór opróżniający komorę sterująca. Ze względu na duży koszt takich zaworów zaproponowano zastosowanie trzech typowych, tanich zaworów elektropneumatycznych $2 / 2$ w celu zróżnicowania czasów napełniania i opróżniania komory sterującej. Każdy z zaworów będzie napełniać i opróżniać komorę sterująca $\mathrm{w}$ innym tempie poprzez odpowiednio dobrane dysze tak, aby uzyskać wymagane przebiegi ciśnienia w funkcji czasu. Schemat ideowy takiego przetwornika przedstawiono na rys. 5 .

Kombinacje załączeń trzech zaworów napełniających i opróżniających umożliwią siedem różnych gradientów napełniania i luzowania komory sterującej. Na rys. 6 przedstawiono przewidywane gradienty napełnień komory sterującej realizowane przez trzy zawory napełniające.

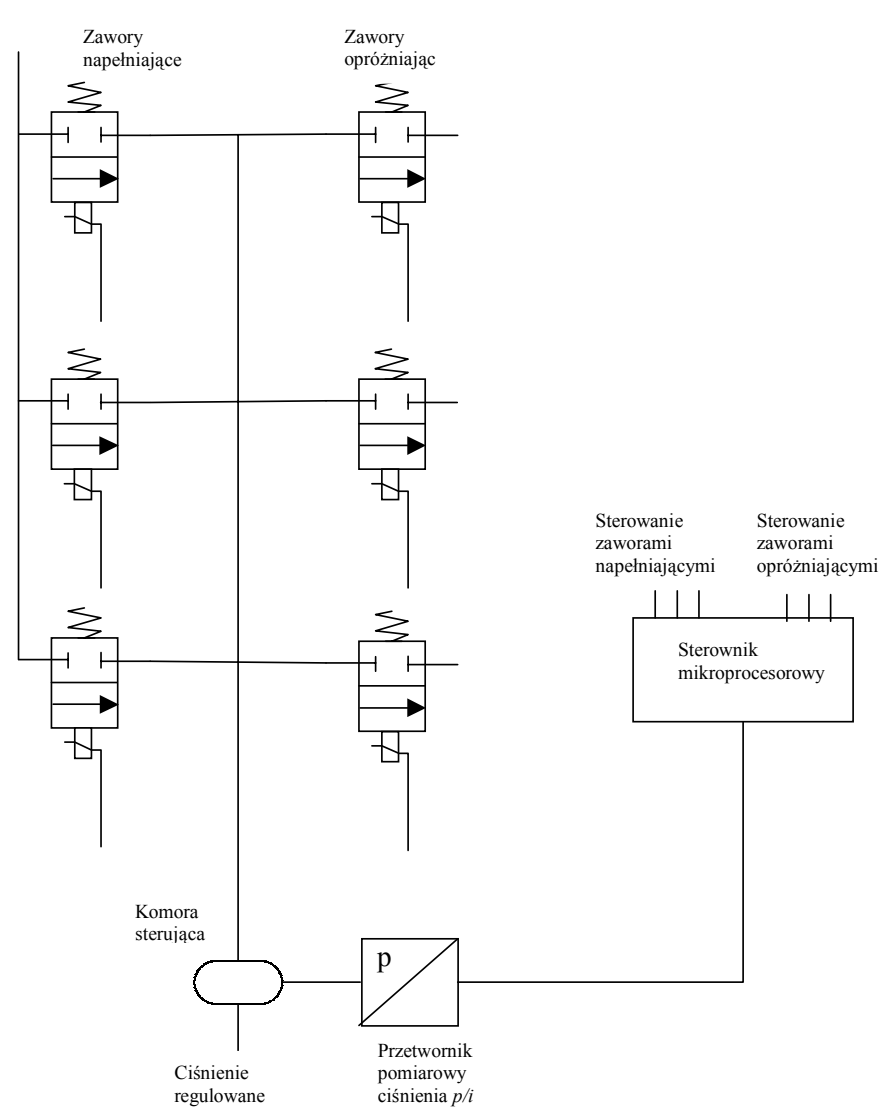

Rys. 5 Cyfrowo-analogowy przetwornik ciśnienia

Na podstawie obliczeń symulacyjnych przeprowadzonych przy pomocy programów opracowanych przez Politechnikę Poznańską $[3,4,5]$ i badań układów napełniających przewód główny, zaprojektowano nowy przekładnik do napełniania przewodu głównego dla lokomotyw. Również na podstawie obliczeń symulacyjnych przyjęto $\mathrm{w}$ realizowanym projekcie, że nowo opracowany przetwornik będzie współpracował ze zbiornikiem sterującym o pojemności 2 do 3 litrów.

Obliczenia symulacyjne wykazały, że pojemność taka we współpracy z nowo opracowanym przekładnikiem, który posiada względnie dużą powierzchnię sterującą i duże przemieszczenia trzona napełniająco-luzującego (wymagane dla zapewnienia dużej dokładności działania i realizowania wymaganych natężeń przepływu sprężonego powietrza), będzie kompromisem zapewniającym właściwą pracę przekładnika i możliwość zastosowania w konstrukcji opracowywanego przetwornika sterującego powszechnie stosowanych zaworów elektropneumatycznych. Wykonano część sprzętową przekładnika i przetwornika do badań i poddano je wstępnym badaniom stanowiskowym. Po uzyskaniu pozytywnych wyników z tych badań IPS Tabor opracował algorytmy sterowania przetwornikiem. Opracowano algorytm sterowania przebiegami ciśnień $\mathrm{w}$ przewodzie głównym spełniający wymagania karty UIC 541-03 [6] i przebiegami ciśnień pod- 
czas napełniania przewodu głównego wysokim ciśnieniem zgodnie z kartą UIC 612-0 [7], oraz normą PN/K-88177 (Hamulec. Wymagania i metody badań). Ze względu na prostsze funkcje realizowane przez hamulec elektropneumatyczny typu bezpośredniego w nowo-opracowanym przetworniku analogowo-cyfrowym dla takiego układu zastosowano jedynie po dwa zawory elektropneumatyczne $\mathrm{w}$ obwodzie napełniania i luzowania komory sterującej, oraz mniejszą pojemność komory sterującej, gdyż do bezpośredniego napełniania cylindrów hamulcowych pojazdów trakcyjnych stosuje się mniejsze przekładniki ciśnienia. Dla tego układu opracowano również algorytm sterowania hamulcem elektropneumatycznym bezpośrednim (do sterowania np. hamulcem EP dla ezt lub hamulcem dodatkowym dla lokomotyw).

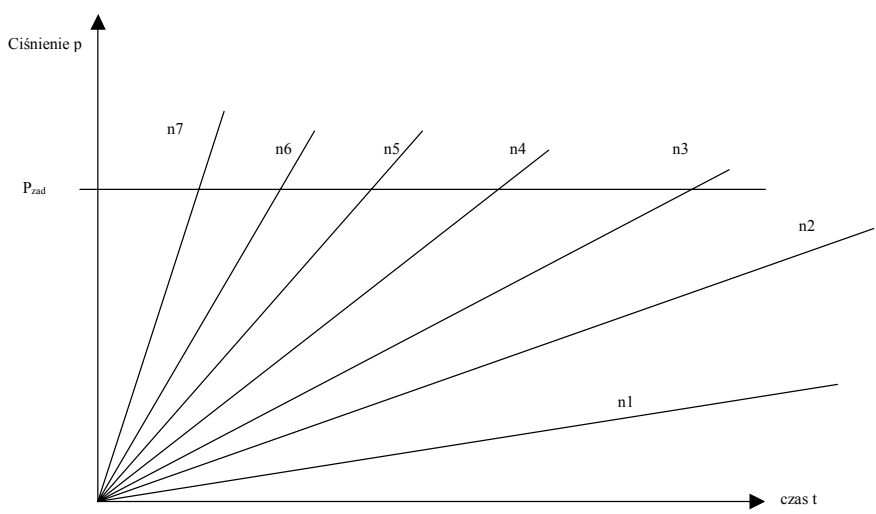

n1 gdy załączony jest ZN1

n2 gdy załączony jest $\mathrm{ZN} 2$

n3 gdy załączony jest ZN1+ ZN2

$\mathrm{n} 4$ gdy załączony jest $\mathrm{ZN} 3$

n5 gdy załączony jest $\mathrm{ZN} 3+\mathrm{ZN} 1$

n6 gdy załączony jest $\mathrm{ZN} 3+\mathrm{ZN} 2$

$\mathrm{n} 7$ gdy załączony jest $\mathrm{ZN} 3+\mathrm{ZN} 2+\mathrm{ZN} 1$

Rys.6 Przewidywane przebiegi napełniania komory sterującej przetwornika cyfrowo-anologowego $e / p$ opartego na trzech zaworach.

\section{Praktyczne realizacje nowego rozwiązania przetwornika cyfrowo-analogowego}

W praktyce dla napełniania i opróżniania komory sterującej przekładnika ciśnienia przewodu głównego zrealizowane zastały w algorytmie przetwornika cztery różne gradienty, dwa zgodne $\mathrm{z}$ wymaganiami międzynarodowymi zawartymi w karcie UIC 541-03 [5] (n2 i n3), jeden duży do szybkich napełnień i luzowań komory sterującej (n7), oraz jeden służący do precyzyjnego utrzymywania wymaganej wartości ciśnienia dla poszczególnych pozycji manipulatora maszynisty(n1).

Natomiast dla przetwornika $e / p$ sterującego procesami napełniającym i luzującym cylindry hamulcowe, realizowanymi przekładnikiem dla hamulca bezpośredniego, zastosowano po dwa gradienty dla każdego z procesów: jeden zapewniający właściwe czasy (napełniania lub luzowania cylindrów hamulcowych) (n3) i drugi służący do precyzyjnego utrzymania wymaganej wartości ciśnienia (n1) dla poszczególnych pozycji manipulatora hamulca dodatkowego.

Przykładowe przebiegi ciśnień sterowanych opracowanymi przetwornikami ciśnienia przedstawiono na rysunkach 7,8 i 9 .

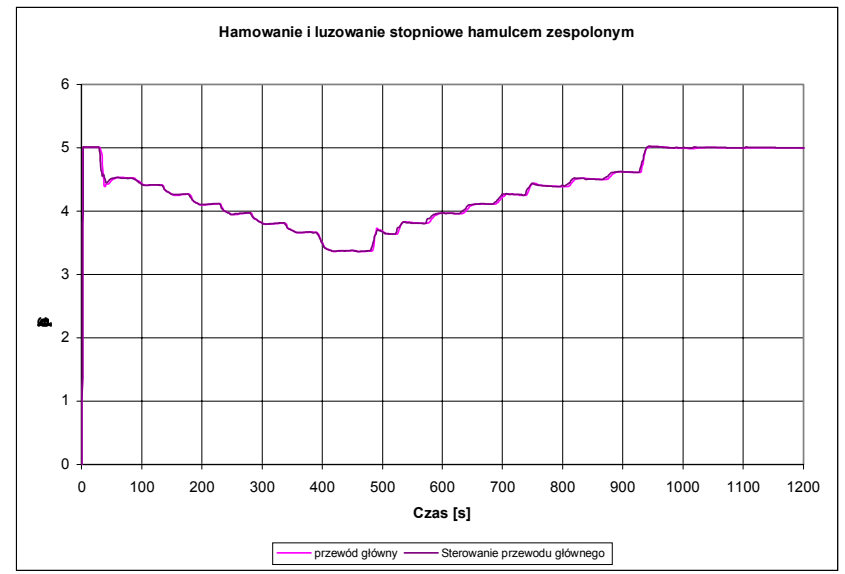

Rys. 7 Przebieg ciśnienia sterującego (kształtowanego mikroprocesorowo przy pomocy przetwornika cyfrowo-analogowego) i ciśnienia $\mathrm{w}$ przewodzie głównym $\mathrm{w}$ hamowaniu oraz luzowaniu stopniowym

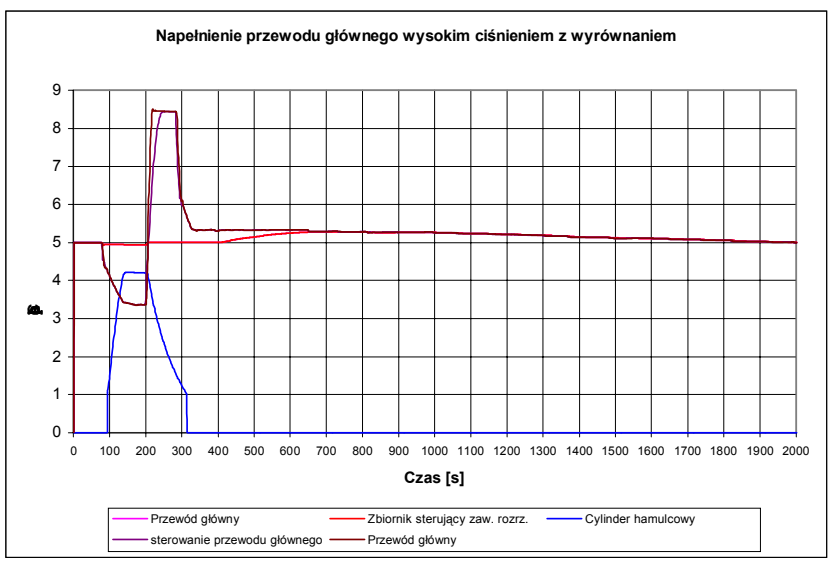

Rys. 8 Przebieg ciśnień w przewodzie głównym sterowanym mikroprcesorowo przy pomocy przetwornika cyfrowo-analogowego podczas napełnienia wysokim ciśnieniem $\mathrm{z}$ wyrównaniem

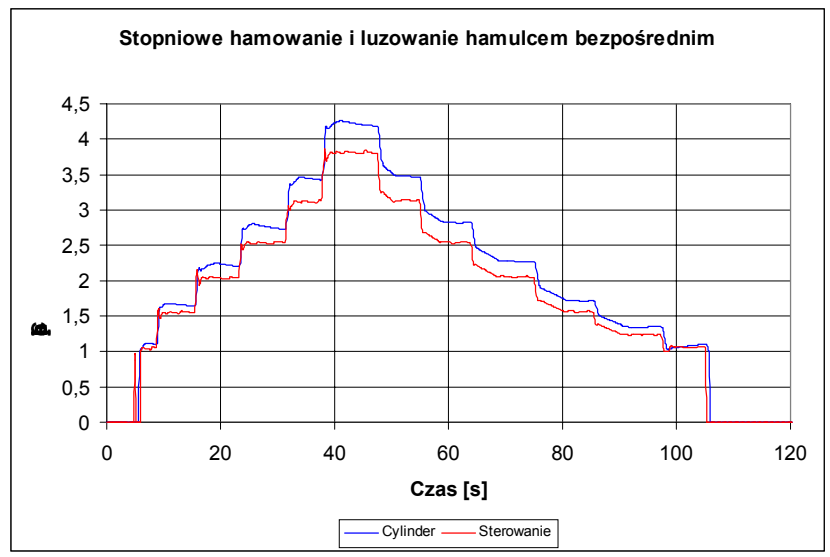

Rys. 9 Stopniowe hamowanie i luzowanie hamulca dodatkowego lokomotywy sterowane mikroprocesorowo przetwornikiem cyfrowo-analogowym 
Na bazie prowadzonych prac badawczo-rozwojowych i na podstawie opracowanej własnej technologii wytwarzania, została uruchomiona w IPS „TABOR” produkcja układów hamulcowych z wykorzystaniem opisanych przetworników. Zapewniły one bardzo dużą dokładność działania (nie do uzyskania dla układów sterowanych sprzętowo), małą histerezę sterowanych układów pneumatycznych $( \pm 2 \mathrm{kPa})$, wysoką powtarzalność realizowanych procesów i istotne uproszczenie sprzętowych układów pneumatycznych hamulca na tablicach pneumatycznych przy niewielkich kosztach samego przetwornika $e / p$.

Ze względu na prostotę układu i precyzję działania nowego układu, zapewnione zostały:

- większa niezawodność działania układu hamulcowego na lokomotywie i w pociagu,

- właściwe parametry hamowania w każdych warunkach eksploatacyjnych (stało się możliwe wdrożenie specjalnych przebiegów jak hamowanie pierwszego stopnia $\mathrm{z}$ dużym gradientem ciśnienia, zapamiętywanie wartości ciśnień w procesach mieszanych: luzowanie wysokim ciśnieniem, hamowanie, luzowanie),

- parametry i przebiegi napełniania wysokim ciśnieniem umożliwiające $\mathrm{w}$ maksymalnym stopniu przyspieszenie napełniania przewodu głównego długich pociagów i uniemożliwiające jednocześnie „przeładowanie” hamulca wagonów w dowolnym pociagu,

- niski koszt układu i niskie koszty jego eksploatacji.

Systemy sterowania według przedstawionego opisu zastosowano po raz pierwszy $w$ tablicach pneumatycznych typu 60ZL dla lokomotyw. Tablice te znalazły zastosowanie w dwu lokomotywach EU07 modernizowanych przez ZNTK Oleśnica, w jednej lokomotywie ST44 modernizowanej przez Bumar-Fablok z Chrzanowa i w modernizowanych przez ZNLE Gliwice lokomotywach ET22. Planowane jest zastosowanie opracowanych przetworników w układach zespołów trakcyjnych realizujących hamulec zespolony pociagu, hamulec elektropneumatyczny bezpośredni i układ współpracy hamulca pneumatycznego $\mathrm{z}$ hamulcem elektrodynamicznym zespołu trakcyjnego.
Układ dla lokomotyw ET22 oparty o nowy przetwornik pn. „Modułowy system sterowania hamowaniem pneumatycznym lokomotywy ze wspomaganiem mikroprocesorowym" został zaprezentowany na Międzynarodowych Targach Poznańskich: Innowacje, Technologie, Maszyny (ITM 2008) i uzyskał złoty medal w kategorii „Transfer wyników badań naukowych do praktyki gospodarczej”.

Prace badawczo-rozwojowe nad nowym przetwornikiem prowadzono w ramach projektu badawczego $\mathrm{Nr}$ 4 T12 C 01530 finansowanego przez Ministerstwo Nauki i Szkolnictwa Wyższego.

\section{Literatura}

[1] Marian Kaluba, Michat Maluśkiewicz: Koncepcje układów elektropneumatycznych pośredniczacych $w$ sterowaniu pneumatycznymi hamulcami pojazdów szynowych. Pojazdy Szynowe, $n r$ 4/2000; str.7-11.

[2] Marian Kaluba: Mikroprocesorowy uktad sterowania systemami hamulców dla zespolów trakcyjnych. Pojazdy Szynowe, $n r$ 4/2007; str.7-10.

[3] Tadeusz Piechowiak: Badania i modelowanie procesów zachodzacych w pneumatycznych uktadach hamulcowych pociagu. Politechnika Poznańska. Rozprawa nr 414. Poznań 2007.

[4] Włodzimierz Gasowski, Tadeusz Piechowiak: Simulation Model of Train's Main Brake Pipe. The Archives of Transport Nr 3/2007.

[5] Tadeusz Piechowiak: Analiza symulacyjna wptywu wybranych parametrów hamulca pneumatycznego na skuteczność jego działania. Pojazdy Szynowe, nr 1/2008 str 14-25.

[6] Karta UIC 541-03. Hamulec Przepisy dla budowy różnych części hamulcowych. Układ zaworu hamulcowego maszynisty. Wydanie z 1.01.1984

[7] Karta UIC 612-0. Driver Machine Interfaces for Locomotives and Driving coaches. Functional and System Requirements associated with harmonized Driver-Machine-Interfaces. 2-nd editio 10-th of April 2007. 